\title{
Phenylbutyrate Ameliorates Cognitive Deficit and Reduces Tau Pathology in an Alzheimer's Disease Mouse Model
}

\author{
Ana Ricobaraza', Mar Cuadrado-Tejedor', Alberto Pérez-Mediavilla', Diana Frechilla', Joaquin Del Río' and \\ Ana García-Osta*,I \\ 'Division of Neurosciences, CIMA, University of Navarra, Pamplona, CIBERNED, Spain
}

\begin{abstract}
Chromatin modification through histone acetylation is a molecular pathway involved in the regulation of transcription underlying memory storage. Sodium 4-phenylbutyrate (4-PBA) is a well-known histone deacetylase inhibitor, which increases gene transcription of a number of genes, and also exerts neuroprotective effects. In this study, we report that administration of 4-PBA reversed spatial learning and memory deficits in an established mouse model of Alzheimer's disease (AD) without altering $\beta$-amyloid burden. We also observed that the phosphorylated form of tau was decreased in the AD mouse brain after 4-PBA treatment, an effect probably due to an increase in the inactive form of the glycogen synthase kinase $3 \beta$ (GSK3 $\beta$ ). Interestingly, we found a dramatic decrease in brain histone acetylation in the transgenic mice that may reflect an indirect transcriptional repression underlying memory impairment. The administration of 4-PBA restored brain histone acetylation levels and, as a most likely consequence, activated the transcription of synaptic plasticity markers such as the GluRI subunit of the AMPA receptor, PSD95, and microtubule-associated protein-2. The results suggest that 4-PBA, a drug already approved for clinical use, may provide a novel approach for the treatment of AD.

Neuropsychopharmacology (2009) 34, I72I-1732; doi:I0.1038/npp.2008.229; published online I4 January 2009
\end{abstract}

Keywords: Alzheimer's disease; phenylbutyrate; histone deacetylase; GSK3 $\beta$; memory

\section{INTRODUCTION}

Alzheimer's disease (AD) is the most common neurodegenerative disorder and the first cause of dementia in the elderly (Cummings and Cole, 2002). AD is defined by progressive memory loss and cognitive impairment, and at the molecular level by the presence of neurofibrillary tangles (NFTs) and insoluble $\beta$-amyloid (A $\beta$ ) plaques (Hardy, 2006). Cognitive processes require gene expression modification to consolidate information (Abel and Kandel, 1998); thus, transcription and translation are critical steps in gene regulation processes underlying memory formation. Transcriptional dysregulation perturbs cellular function leading to neuronal death, and therefore, it may play a role in the cognitive impairment and the pathogenesis of $\mathrm{AD}$. A well-recognized mechanism of transcriptional regulation is chromatin modification through histone acetylation. Generally, acetylated histones form active chromatin complexes with DNA, which makes the DNA accessible to RNA polymerases, thereby regulating gene transcription (Strahl and Allis, 2000). Histone deacetylase (HDAC) inhibitors increase acetylation of histones, promoting transcriptional

\footnotetext{
*Correspondence: Dr A García-Osta, Division of Neurosciences, CIMA, University of Navarra, Av. Pio XII 55, Pamplona, CIBERNED 31008, Spain, Tel: + 01134948194700201 I, Fax: 01 I 349481947 15, E-mail: agosta@unav.es

Received 18 August 2008; revised 14 November 2008; accepted 2 December 2008
}

activation. Of the five classes of HDAC inhibitors, the butyrates are the most developed for clinical use because they are able to penetrate the blood-brain barrier (Cremer et al, 1977; Collins et al, 1995). Sodium 4-phenylbutyrate (4-PBA), an orally bioavailable short-chain fatty acid originally approved for treatment of urea cycle disorders (Brusilow and Maestri, 1996), is a HDAC inhibitor that activates transcription of a variety of genes involved in the regulation of cell development and proliferation (Wright et al, 2004). The formation of long-term memories is thought to entail lasting changes in gene expression that are necessary for memory consolidation (Bailey et al, 2004). There is growing evidence that HDAC inhibitors, by modifying chromatin structure, can regulate long-term functional changes in the nervous system and have the potential to boost memory formation (Levenson et al, 2004; Levenson and Sweatt, 2005). Recent report showed that increased histone acetylation by administration of an HDAC inhibitor facilitated memory performance in young mice (Levenson et al, 2004; Vecsey et al, 2007; Bredy and Barad, 2008) and reversed learning and consolidation deficits in different neurodegeneration mice model (Fischer et al, 2007; Fontán-Lozano et al, 2008). The improvement in learning and memory was correlated with the upregulation of synaptic and dendritic growth markers, suggesting a new mechanism that may improve memory.

The pathophysiology of many neurodegenerative disorders, such as $\mathrm{AD}$, involves multiple mechanisms. HDAC inhibitors have been shown to be neuroprotective in 
different models of central nervous system disorders such as polyglutamine disorders (Ferrante et al, 2003; Minamiyama et al, 2004), spinal muscular atrophy (Chang et al, 2001), ischemia (Qi et al, 2004), Huntington (Gardian et al, 2005), Parkinson (Gardian et al, 2004), and amyotrophic lateral sclerosis (ALS) (Ryu et al, 2005). Given that there is no effective treatment for $\mathrm{AD}$, we assessed in this study the potential capability of 4-PBA, through its HDAC inhibitory activity, to reverse the learning and memory impairment in an $\mathrm{AD}$ mouse model and the possible correlation with $\mathrm{AD}$ pathology markers.

\section{MATERIALS AND METHODS}

\section{Mouse Model and Treatment}

In this study, we used Tg2576 $\mathrm{AD}$ transgenic mice that express the human 695-aa isoform of APP containing the Swedish double mutation (APPswe) [(APP695)Lys670 $\rightarrow$ Asn, Met671 $\rightarrow$ Leu] driven by a hamster prion promoter. In the Tg2576 AD mouse model, A $\beta$ peptide content in the brain accumulates exponentially between 7 and 12 months of age, and mice show impaired memory in the water maze test at the age of 12-15 months (Hsiao et al, 1996). Therefore, we treated 16-month-old female Tg2576 mice once daily with 4 -PBA $(200 \mathrm{mg} / \mathrm{kg}$, i.p. $)$ or vehicle for 5 weeks. The dose was chosen based on a dose-response experiment (Ryu et al, 2005) performed using increasing doses of PBA from 100 to $800 \mathrm{mg} / \mathrm{kg}$ to determine the most efficacious dose. 4-PBA solution was prepared by titrating equimolecular amounts of 4-phenylbutyric acid (Sigma, Madrid, Spain) and sodium hydroxide to $\mathrm{pH}$ 7.4. As a control we used a group of age- and strain-matched nontransgenic mice. All procedures were carried out in accordance with European and Spanish regulations (86/ 609/CEE; RD1201/2005). This study was approved by the Ethical Committee of the University of Navarra (no. 018/ 05).

\section{Morris Water Maze Test}

We used the Morris water maze (MWM) test to evaluate the working and reference memory function in response to treatment with 4-PBA in $\mathrm{Tg} 2576$ mice, as previously described (Ribé et al, 2005). Groups of female Tg2576 mice treated with 4-PBA $(n=8)$, or vehicle $(n=8)$ and nontransgenic littermates $(n=10)$ underwent spatial reference learning and memory testing in the MWM test at 16 months of age. The water maze was a circular pool (diameter $1.2 \mathrm{~m}$ ) filled with water maintained at $20^{\circ} \mathrm{C}$ and made opaque by the addition of non-toxic white paint. Mice underwent visible-platform training for 3 consecutive days (eight trials per day) using a platform raised above the surface of the water. No visible cues were present during this phase. This was followed by hidden-platform training (with all visible cues present) during which mice were trained to locate a platform in the opposite quadrant and submerged $1 \mathrm{~cm}$ beneath the surface for 9 consecutive days (four trials per day). In both visible- and hidden-platform versions, mice were placed pseudo-randomly in selected locations, facing toward the wall of the pool to eliminate the potentially confounding contribution of extramaze spatial cues. Each trial was terminated when the mouse reached the platform or after $60 \mathrm{~s}$, which ever came first. Mice failing to reach the platform were guided onto it. After each hidden-platform trial, mice remained on the platform for $20 \mathrm{~s}$. Twenty hours after the 12th, 24th, and 32nd trials, all mice were subjected to a probe trial in which they swam for $60 \mathrm{~s}$ in the pool with no platform. Mice were monitored by a camera mounted in the ceiling directly above the pool, and all trials were recorded using an HVS water maze program for subsequent analysis of escape latencies, swimming speed, path length, and percent time spent in each quadrant of the pool during probe trials (analysis program WaterMaze3, Actimetrics, Evanston, IL). All experimental procedures were performed blind to groups.

\section{Determination of $A \beta$ Levels}

Cortical $\mathrm{A} \beta 42$ and $\mathrm{A} \beta 40$ levels were measured by using a sensitive sandwich ELISA kit from Biosource (Camarillo, CA). In brief, tissue was weighed and homogenized in $8 \times$ mass of ice-cold guanidine buffer $(5 \mathrm{M}$ guanidine $\mathrm{HCl} /$ $50 \mathrm{mM}$ Tris- $\mathrm{HCl} \mathrm{pH} \mathrm{8.0).} \mathrm{The} \mathrm{homogenates} \mathrm{were} \mathrm{mixed} \mathrm{for}$ $4 \mathrm{~h}$ at room temperature and were diluted $1: 50$ in Dulbecco's phosphate-buffered saline containing 5\% BSA and $0.03 \%$ Tween-20 (DPBS-BSAT) supplemented with protease inhibitor cocktail (CompleteTM Protease Inhibitor Cocktail, Roche Diagnostics, Mannheim, Germany) followed by centrifugation at $16000 \mathrm{~g}$ for $20 \mathrm{~min}$ at $4^{\circ} \mathrm{C}$. The supernatant was diluted and loaded onto ELISA plates in duplicate, and the manufacturer's instructions were followed. The $\mathrm{A} \beta$ standards were prepared in a buffer with the same composition of final tissue samples.

\section{Production of Protein Extracts}

Mice were killed by cervical dislocation and hippocampi were quickly dissected from the brains. Total tissue homogenates were obtained by homogenizing the hippocampus in ice-cold RIPA buffer (50 mM Tris- $\mathrm{HCl} \mathrm{pH}$ 7.4, $0.25 \%$ DOC, $1 \%$ Nonidet P- $40,150 \mathrm{mM} \mathrm{NaCl}, 1 \mathrm{mM}$ EDTA, $1 \mathrm{mM}$ PMSF, $1 \mu \mathrm{g} / \mathrm{ml}$ leupeptin, $1 \mu \mathrm{g} / \mathrm{ml}$ aprotinin, $1 \mathrm{mM}$ $\mathrm{Na}_{3} \mathrm{VO}_{4}, 1 \mathrm{mM} \mathrm{NaF}$ ), centrifuged at $14000 \times g 4^{\circ} \mathrm{C}$ for $20 \mathrm{~min}$, and the supernatant was aliquoted and frozen at $-80^{\circ} \mathrm{C}$. To obtain the membrane-enriched protein fraction (P2 membrane proteins), a previously described method (Dunah et al, 2000) was used. The hippocampi were homogenized in ice-cold Tris-EDTA buffer $(10 \mathrm{mM}$ Tris$\mathrm{HCl}$ and $5 \mathrm{mM}$ EDTA, $\mathrm{pH}$ 7.4), containing $320 \mathrm{mM}$ sucrose and the protease and phosphatase inhibitors previously described. The tissue homogenate was centrifuged at $700 \times g$ for $10 \mathrm{~min}$. The collected supernatant was centrifuged again at $37000 \times g$ for $40 \mathrm{~min}$ at $4^{\circ} \mathrm{C}$. Finally, the pellet (P2) was resuspended in $10 \mathrm{mM}$ Tris- $\mathrm{HCl}$ buffer ( $\mathrm{pH} 7.4)$, containing the enzyme inhibitor mixture described above. In both cases, protein concentration was determined (Bradford assay, BioRad Laboratories, Hercules, CA) and aliquots were stored at $-80^{\circ} \mathrm{C}$ until used. For western blot analysis, aliquots of the P2 membrane fraction were solubilized in denaturing conditions by adding 0.1 volume of $10 \%$ sodium deoxycholate in $500 \mathrm{mM}$ Tris- $\mathrm{HCl}$ buffer $\left(\mathrm{pH}\right.$ 9). The samples were incubated for $30 \mathrm{~min}$ at $36^{\circ} \mathrm{C}$ and diluted by adding 0.1 volume of $500 \mathrm{mM}$ Tris- $\mathrm{HCl}$ 
( $\mathrm{pH} 9) / 1 \%$ Triton $\mathrm{X}-100$. After a centrifugation step at $37000 \times g$ for $10 \mathrm{~min}$ at $4^{\circ} \mathrm{C}$, the supernatant was stored at $-80^{\circ} \mathrm{C}$.

For histone analysis, extracts from mice frontal cortex were obtained by homogenization in a cold lysis buffer with protease inhibitors $(0.2 \mathrm{M} \mathrm{NaCl}, 0.1 \mathrm{M}$ HEPES, $10 \%$ glycerol, $200 \mathrm{mM} \mathrm{NaF}, 2 \mathrm{mM} \mathrm{Na} \mathrm{P}_{2} \mathrm{O}_{7}, 5 \mathrm{mM}$ EDTA, $1 \mathrm{mM}$ EGTA, $2 \mathrm{mM}$ DTT, $0.5 \mathrm{mM}$ PMSF, $1 \mathrm{mM} \mathrm{Na} \mathrm{VO}_{4}, 1 \mathrm{mM}$ benzamidine, $10 \mu \mathrm{g} / \mathrm{ml}$ leupeptin, $400 \mathrm{U} / \mathrm{ml}$ aprotinin), centrifuged at $14000 \times g \quad 4{ }^{\circ} \mathrm{C}$ for $20 \mathrm{~min}$, and the supernatant was aliquoted and stored at $-80^{\circ} \mathrm{C}$. Total protein concentrations were determined using the BioRad Bradford protein assay (BioRad Laboratories).

\section{Immunoblotting}

Protein samples were mixed with an equal volume of $2 \times$ Laemmli sample buffer, resolved onto SDS-polyacrylamide gels and transferred to nitrocellulose membrane. The membranes were blocked with $5 \%$ milk, $0.05 \%$ Tween-20 in PBS or TBS followed by overnight incubation with the following primary antibodies: mouse monoclonal antiphospho tau AT8 (Pierce Biotechnology Inc., Rockford), mouse monoclonal anti tau (clone Tau46, Sigma-Aldrich, St Luis, MO), rabbit polyclonal anti-pGSK3-Ser9 (Cell Signalling Technology, Beverly, MA), rabbit polyclonal anti-GSK3 (Santa Cruz Biotechnology, Santa Cruz, CA), rabbit polyclonal anti-acetylated histone 4 (acetyl $\mathrm{K} \mathrm{5/8/12/16)}$ and 3 (acetyl K9/14) (Upstate Biotechnology, Lake Placid, NY), rabbit polyclonal anti-GluR1, mouse monoclonal antiPSD95, rabbit polyclonal anti-MAP2 (Chemicon, Temecula, CA) mouse monoclonal anti-actin, and mouse monoclonal anti-tubulin (Sigma) in the corresponding buffer. All the antibodies were used at 1:1000 dilution except the mouse monoclonal anti-actin and mouse monoclonal anti-tubulin that were used at 1:10000. Following two washes in PBS or TBS/Tween20 and one wash in PBS or TBS alone, immunolabeled protein bands were detected by using HRP-conjugated anti-rabbit or anti-mouse antibody (Santa Cruz; dilution $1: 5000)$ following an enhanced chemiluminiscence system (ECL, GE Healthcare Bioscience, Buckinghamshire, UK), and autoradiographic exposure to Hyperfilm $^{\mathrm{TM}}$ ECL (GE Healthcare Bioscience). Signals quantification was performed using Scion Image software (Scion Corporation).

\section{Immunohistochemistry}

Floating tissue sections comprising hippocampal formation were processed for immunohistochemistry. Brain sections were washed $(3 \times 10 \mathrm{~min})$ with $0.125 \mathrm{M}$ phosphate buffer $(\mathrm{pH}$ 7.4) and incubated in blocking solution (PBS containing $0.5 \%$ Triton $\mathrm{X}-100,0.1 \% \mathrm{BSA}$ and $2 \%$ normal goat serum) for $2 \mathrm{~h}$ at room temperature. For $6 \mathrm{E} 10$ immunostaining, sections were incubated in $70 \%$ formic acid for $7 \mathrm{~min}$ to expose the epitope. Primary and secondary antibodies were diluted in the blocking solution. Sections were incubated with the primary antibodies for $24 \mathrm{~h}$ at $4{ }^{\circ} \mathrm{C}$, washed with PBS and incubated with the secondary antibody for $2 \mathrm{~h}$ at room temperature, protected from light. The primary antibodies used were as follows: mouse monoclonal 6E10 (amino acids $1-17$ of $\mathrm{A} \beta$ peptide, 1:200,
Chemicon), rabbit polyclonal anti-acetylated histone 4 (acetyl K8, 1:600, Upstate), mouse monoclonal anti-neuronal nuclei (NeuN, 1:150, Millipore), and rabbit polyclonal antiMAP2 (1:1000, Chemicon). Secondary antibodies used were Alexa Fluor 488 goat anti-mouse, highly cross-absorbed, and Alexa Fluor 546 goat anti-rabbit, highly cross-absorbed (both 1:200, Molecular Probes, Eugene, Oregon). Sections were mounted on super frost plus slides, air dried for $24 \mathrm{~h}$, rinsed in toluene $(2 \times 5 \mathrm{~min})$, and coverslip with DPX mounting medium. To ensure comparable immunostaining, sections were processed together under identical conditions. For the assessment of nonspecific primary immunostaining, some sections from each experimental group were incubated without the primary antibodies; in this case no immunostaining was observed. Nonspecific secondary immunostaining was also evaluated by incubating sections with primary and its nonspecific secondary antibodies; again, no immunostaining was observed. Fluorescence signals were detected with confocal microscope LSM 510 Meta (Carl Zeiss, Germany); objective Plan-neofluar $40 \times / 1.3$ oil DIC. Sections were evaluated in Z-series $(0.4 \mu \mathrm{m}$ steps $)$ using LSM 510 Meta software.

\section{Primary Neuronal Cultures}

Primary neuronal cultures were derived from the hippocampus of embryonic day 16 (E16) Tg2576 or nontransgenic mice. Hippocampi were triturated using glass pipettes until neurons were dissociated. Neurons were plated in serum-free neurobasal media with B27 supplement (Invitrogen, Gaithersburg, MD) and $2 \mathrm{mM}$ L-glutamine on poly-L-lysine-treated $(0.1 \mathrm{mg} / \mathrm{ml}$; Sigma) $60 \mathrm{~mm}$ dishes. To maintain elevated levels of extracellular $\mathrm{A} \beta$, media were not changed. No differences in cell viability were detected by Trypan blue staining or lactate dehydrogenase release between wild-type and transgenic neurons at 12 or 19 days in vitro (DIV). Primary neurons were viable for $>3-4$ weeks under our culturing conditions. For western blot, $\sim 2 \times 10^{6}$ neurons were plated per $60-\mathrm{mm}$ diameter. Genotyping was performed on cerebellum from the same embryo.

Hippocampal cultures at 19 DIV were treated for 4 days with 4 -PBA $(2 \mathrm{mM})$ and $1 \mathrm{~h}$ after the last treatment (22 DIV), hippocampal cells were collected in a cold lysis buffer with protease inhibitors $(0.2 \mathrm{M} \mathrm{NaCl}, 0.1 \mathrm{M} \mathrm{HEPES,} 10 \%$ glycerol, $200 \mathrm{mM} \mathrm{NaF}, 2 \mathrm{mM} \mathrm{Na} \mathrm{P}_{2} \mathrm{O}_{7}, 5 \mathrm{mM}$ EDTA, $1 \mathrm{mM}$ EGTA, $2 \mathrm{mM}$ DTT, $0.5 \mathrm{mM}$ PMSF, $1 \mathrm{mM} \mathrm{Na} \mathrm{VO}_{4}, 1 \mathrm{mM}$ benzamidine, $10 \mu \mathrm{g} / \mathrm{ml}$ leupeptin, $400 \mathrm{U} / \mathrm{ml}$ aprotinin), centrifuged at $14000 \times g 4^{\circ} \mathrm{C}$ for $20 \mathrm{~min}$ and the supernatant was aliquoted and stored at $-80^{\circ} \mathrm{C}$. Total protein concentrations were determined using the BioRad Bradford protein assay (BioRad Laboratories).

\section{Chromatin Immunoprecipitation Assays}

Chromatin immunoprecipitation (ChIP) assays were performed to measure the levels of histone 4 acetylation at various promoter regions. Whole hippocampus and cortex were removed and immediately crosslinked in $1 \%$ formaldehyde for $15 \mathrm{~min}$ at room temperature. The crosslinking reaction was stopped by washing the tissue in PBS containing glycine to a final concentration of $0.125 \mathrm{M}$. The tissue was washed three times with ice-cold PBS, and lysed 
in $10 \mathrm{mM}$ Tris- $\mathrm{HCl}$ ( $\mathrm{pH} 8), 0.25 \%$ Triton, $0.5 \%$ NP-40, $10 \mathrm{mM}$ EDTA, $0.5 \mathrm{mM}$ EGTA, and proteinase inhibitors. Nuclei were pelleted at $3000 \mathrm{~g}$ and resuspended in $50 \mathrm{mM}$ Tris- $\mathrm{HCl}$ ( $\mathrm{pH} 8$ ), $10 \mathrm{mM}$ EDTA, 1\% SDS, and proteinase inhibitors. Chromatin was sheared into approximately 500bp fragments using a Bandelin sonicator (10 cycles at $30 \mathrm{~s}$ each, at $30 \%$ maximum power) followed by centrifugation to pellet debris. Aliquots $(300 \mu \mathrm{l})$ with supernatant proteins were diluted with ChIP dilution buffer $(16.7 \mathrm{mM}$ Tris- $\mathrm{HCl}$ (pH 8), $167 \mathrm{mM} \mathrm{NaCl}, 1.2 \mathrm{mM}$ EDTA, $0.01 \%$ SDS, $1.1 \%$ Triton, and protease inhibitors) to a final volume of $1.5 \mathrm{ml}$. One hundred microliters of the pre-immunoprecipitated lysate was saved as 'input' for later normalization. The chromatin solution was pre-cleared with protein A-agarose beads (Pierce, Rockford, IL) for $45 \mathrm{~min}$. It was then immunoprecipitated overnight at $4{ }^{\circ} \mathrm{C}$ with $5 \mu \mathrm{g}$ of antibody directed against $\mathrm{H} 4$ acetylated at Lys5, Lys8, Lys12, and Lys16 (cat number 06-866; Upstate Biotechnology). The specificity of this antibody in ChIP assays has been established (Huang et al, 2002). As a control, samples were immunoprecipitated with $5 \mu \mathrm{g}$ nonimmune rabbit IgG (Upstate Biotechnology). After immunoprecipitation, the DNA-histone complex was collected with $40 \mu \mathrm{l}$ protein A-agarose beads for $2 \mathrm{~h}$. The beads were sequentially washed once with low salt $(20 \mathrm{mM}$ Tris- $\mathrm{HCl}(\mathrm{pH})$, $150 \mathrm{mM} \mathrm{NaCl}, 2 \mathrm{mM}$ EDTA, $0.1 \%$ SDS, 1\% Triton), high salt (20 mM Tris-HCl (pH 8), $1500 \mathrm{mM} \mathrm{NaCl}, 2 \mathrm{mM}$ EDTA, $0.1 \%$ SDS, $1 \%$ Triton), and $\mathrm{LiCl}$ (10 mM Tris- $\mathrm{HCl}(\mathrm{pH} 8)$, $0.25 \mathrm{mM} \mathrm{LiCl}, 1 \% \mathrm{NP} 40,1 \%$ deoxycolate, $1 \mathrm{mM}$ EDTA) and washed twice with $10 \mathrm{mM}$ Tris- $\mathrm{HCl}(\mathrm{pH}$ 8)/1 mM EDTA (TE) buffers. Protein-DNA complexes were then eluted from protein A-agarose beads by two washings with a freshly prepared solution ( $50 \mathrm{mM} \mathrm{NaHCO} 3,1 \% \mathrm{SDS}$ ), with brief shaking and further centrifugation $(1000 \mathrm{~g}, 5 \mathrm{~min})$. DNA and histones were dissociated at $65^{\circ} \mathrm{C}$ for $4 \mathrm{~h}$ under high-salt conditions. Before PCR, immunoprecipitates and corresponding input chromatin were digested with proteinase $\mathrm{K}$ and extracted with phenol/chloroform/isoamyl alcohol, precipitated with $100 \%$ ethanol, and finally resuspended in $80 \mu \mathrm{l}$ of PCR-grade water.

\section{Quantification of DNA by Real-Time PCR}

The levels of specific histone modifications at each gene promoter of interest were determined by measuring the amount of acetylated histone-associated DNA by quantitative real-time PCR (ABI Prism 7700; Applied Biosystems, Foster City, CA). Specific primers were designed to amplify proximal promoter regions, $<200 \mathrm{bp}$ long. For AMPA receptor subunit GluR1: forward 5'-TGCTCCCGGCTCAGT TAATC- $3^{\prime}$ and reverse 5'-TCTTTTCTTCCTGCAA-3', amplified a region $240-90$ bp upstream of the start codon. For the housekeeping gene B2m: forward, 5'-GGGAAAGTCC CTTTGTAACCT-3'; reverse, 5'-GCGCGCGCTCTTATA TAGTT-3'. 'Input' or total DNA (used for normalization) and immunoprecipitated DNA were PCR amplified in triplicate in the presence of SYBR Green (Applied Biosystem). PCRs were run in triplicates for each brain sample and four brain pairs were used for statistical analysis. $C_{\mathrm{t}}$ values of immunoprecipitated samples were normalized to $C_{\mathrm{t}}$ values obtained from 'input', and the quantification was carried out using the delta-delta method
(Livak and Schmittgen, 2001). Mean and SEM values were determined for each fold difference, and these values were used in $t$-tests to determine statistical significance $(p<0.05)$.

\section{Statistical Analysis}

The results were processed for statistical analysis using the SPSS for Windows package. Unless otherwise indicated, results are presented as mean \pm SEM. In the MWM test, escape latencies during training were analyzed using oneway analysis of variance (ANOVA) followed by Scheffé post hoc test. The Friedman test was performed to determine the intra group comparisons over trials. Biochemical data were analyzed using one-way ANOVA followed by Scheffé post hoc multiple-comparison test or Student's $t$-test. The significance level was set at $p<0.05$.

\section{RESULTS}

\section{Morris Water Maze Test}

To study the effects of 4-PBA on cognition, we tested whether 5 weeks of treatment would alleviate the learning deficit exhibited by 16-month-old Tg2576 mice on the MWM test. No significant differences among groups were found during the days of visible-platform training (Figure 1a). In the spatial component of the test (invisible platform), the escape latencies showed significant differences among groups $\left(\mathrm{F}_{(2,691)}=22.8 ; p<0.001\right)$. The transgenic mice treated with the vehicle were impaired in their performance in this test $v s$ age-matched non-transgenic mice. By contrast, transgenic mice treated with 4-PBA performed similar to age-matched control mice during every day of the training period (Figure 1b).

After the 12, 24, and 32 trial, all mice were subjected to a probe trial in which they swam in the pool with the platform removed as a putative measurement of memory retention. It has been suggested that the sensitivity of the MWM test can be increased by giving shorter probe trials (Gerlai, 2001), thereby, we analyzed the performance of mice during the first 15s (Figure 1c) and $60 \mathrm{~s}$ (Figure 1d) of every probe trial. ANOVA showed significant differences among groups in both 15 and $60 \mathrm{~s}$ probe trials $\left(\mathrm{F}_{(2,50)}=6.1 ; p<0.01\right.$, $\left.\mathrm{F}_{(2,50)}=10.2 ; p<0.001\right)$. The percent of time spent in the target quadrant was significantly lower for transgenic mice treated with vehicle $v s$ the non-transgenic mice and $v s$ transgenic mice that underwent 4-PBA treatment. This last group spent a percent of time in the target quadrant that did not differ from that of the age-matched non-transgenic group (Figure $1 \mathrm{c}$ and $\mathrm{d}$ ). The swim speed did not differ significantly between groups and the distance data exhibited the same pattern of as escape latency data (data not show). These data suggest that 4-PBA administered chronically improves water maze memory function in Tg2576 mice.

To see intra-group comparisons, we analyzed the latencies in the hidden-platform training over trials using the Friedman repeated measures nonparametric test. The mean latencies spent to reach the platform decreased over the training sessions for the non-transgenic mice $\left(\chi^{2} r=16.82, p<0.01\right)$ and for the 4-PBA-treated group $\left(\chi^{2} r=16.17, p<0.01\right.$, Friedman's test). On the contrary, the 

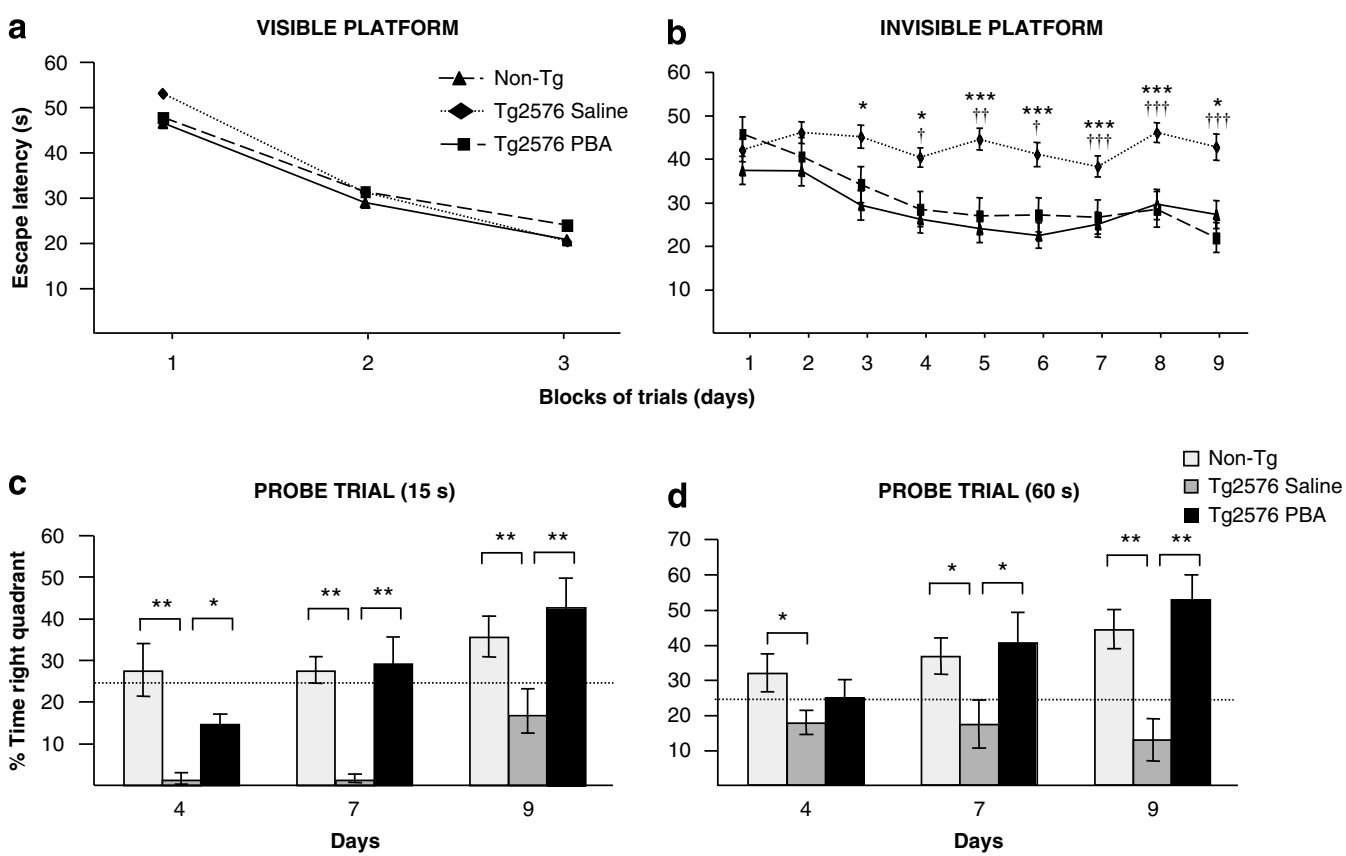

Figure I 4-PBA treatment reverses spatial memory deficits in 16-month-old Tg2576 mice in the Morris water maze test. (a) Escape latency in the visible platform training. No significant differences were detected among groups during any of the 3 days of visible-platform training. (b) Escape latency in the invisible-platform training. Saline-treated Tg2576 mice showed significantly longer escape latencies in the invisible-platform training when compared with non-transgenic littermate (Non-Tg) controls (*p $<0.05$, **** $p<0.00$ I. ANOVA with Scheffe's post hoc test) and to 4-PBA-treated group ( ${ }^{\dagger} p<0.05$, ${ }^{\dagger \dagger} p<0.01$, ${ }^{\dagger \dagger} p<0.001$; ANOVA with Scheffe's post hoc test). Values are the mean \pm SEM $(n=7-8)$. ( $c$ and $\left.d\right)$ Percentage time spent in the training quadrant during 15 (c) and 60 s (d) probe trials. Saline-treated Tg2576 mice performed significantly worse than 4-PBA-treated or Non-Tg littermate controls in the three 15- and 60-s probe trials ( ${ }^{*} p<0.05$, ${ }^{*} * x<0.01$, ANOVA with Scheffe's post hoc tests).

latencies exhibited by the saline-treated group did not decrease significantly over trial $\left(\chi^{2} r=6.22, p>0.01\right)$. The results indicated that non-transgenic and 4-PBA-treated animals tended to learn correctly the platform location, whereas saline-treated animals did not. Specifically, intragroup comparisons of escape latencies showed a significant effect of the training only for the non-transgenic and 4PBA-treated groups. Saline-treated group did not show a significant reduction in their escape latencies from days 2 to 9, compared with the first training day.

\section{AD Pathology Markers}

Because 4-PBA treatment showed a clear benefit on memory acquisition and retention, we next explored its effect on the $\mathrm{A} \beta$ levels in Tg2576 mice. Mice were killed $24 \mathrm{~h}$ after the last training trial in the MWM test. The cortex and the hippocampi were dissected and used for biochemical analysis. The levels of $\mathrm{A} \beta_{40}$ and $\mathrm{A} \beta_{42}$ were determined in the cerebral cortex by sandwich ELISA. As shown in Figure $2 \mathrm{a}$, no difference was seen in $\mathrm{A} \beta_{40}$ or $\mathrm{A} \beta_{42}$ levels in Tg2576 mice treated with vehicle compared with 4-PBAtreated transgenic mice. No $\mathrm{A} \beta$ was detected in nontransgenic littermates. Similar results were obtained by $\mathrm{A} \beta$ immunoreactivity to stain plaque load in the hippocampus (Figure 2b). 6E10 immunofluorescence illustrated similar A $\beta$ plaque load in the saline-treated compared with the 4-PBA-treated Tg2576 mice.

Next, we analyzed the levels of tau phosphorylation in the mice hippocampi using a phospho-specific antibody, AT8 that recognize aberrantly hyperphosphorylated epitopes on
Ser-202/Thr-205 and normalized to total tau (T46). As depicted in Figure $3 \mathrm{a}$, a one-way ANOVA showed a significant group effect $\left(\mathrm{F}_{(2,18)}=7.0 ; p<0.01\right)$. Scheffe's multiple-comparison test showed that phosphorylation of tau was increased in the hippocampus of 16-month-old Tg2576 (176.2 $\pm 11.6 \%$; $\left.{ }^{*} p<0.01\right)$ compared with nontransgenic mice $(100.6 \pm 13.2 \%)$. Interestingly, we found no differences in tau phosphorylated at the AT8 site in transgenic mice treated with 4-PBA $(125.0 \pm 7.4 \%)$ compared with non-transgenic mice (Figure 3a). Total tau levels normalized using actin did not show significant changes among groups (data not show).

Phosphorylation of tau is regulated by various protein kinases and phosphatases. Glycogen synthase kinase $3 \beta$ $($ GSK3 $\beta$ ) is responsible for phosphorylating Ser202 of tau protein (AT8 immnunoreactivity) (Mandelkow et al, 1992, 1995). We measured the levels of inactive GSK3 $\beta$, phosphorylated at Ser 9 (pGSK3 $\beta$-Ser9) normalized to GSK3 $\beta$. A one-way ANOVA showed a significant group effect $\left(\mathrm{F}_{(2,12)}=7.6 ; p<0.05\right)$. Scheffe's multiple-comparison test showed that pGSK3 $\beta$-Ser9 levels were higher in the hippocampus of transgenic mice treated with 4-PBA (127.1 $\pm 8.1 \%$ vs Non-Tg: $100.9 \pm 11.5 \%)$ compared with vehicle-treated mice (69.1 $\pm 9.3 \%$; Figure $3 \mathrm{~b})$. Total GSK3 $\beta$ levels normalized using actin did not show significant changes among groups (data not show).

\section{Histone Acetylation}

Histone acetylation mediates transcriptional regulation of gene expression through chromatin modification, and has 

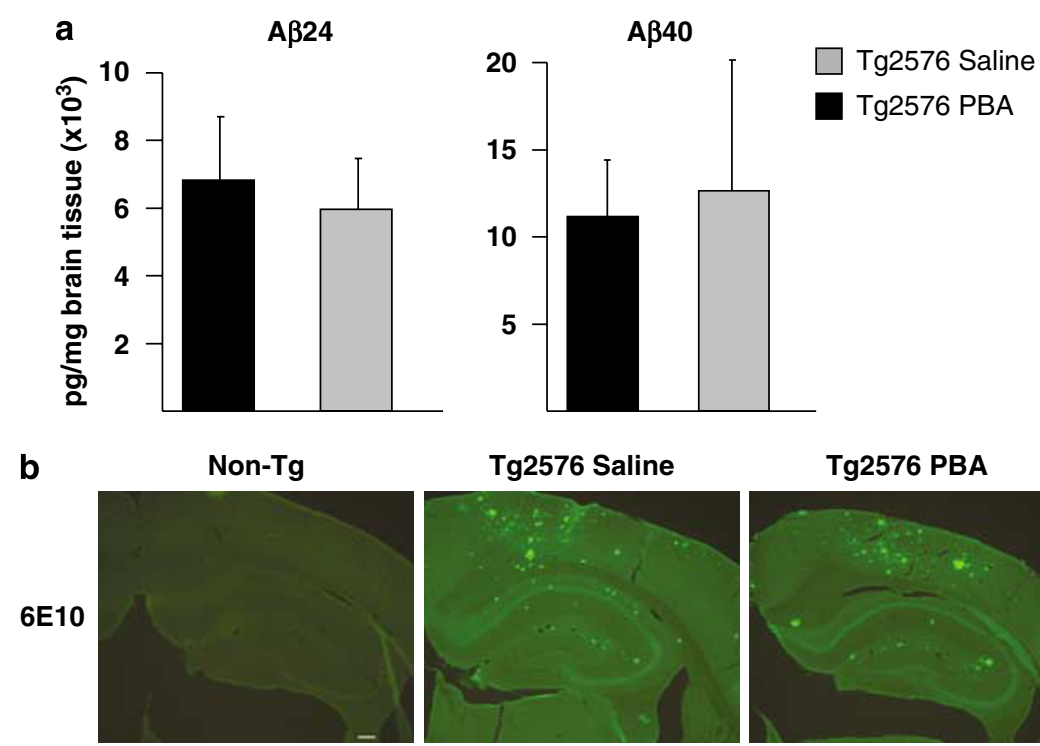

\section{Tg2576 Saline}
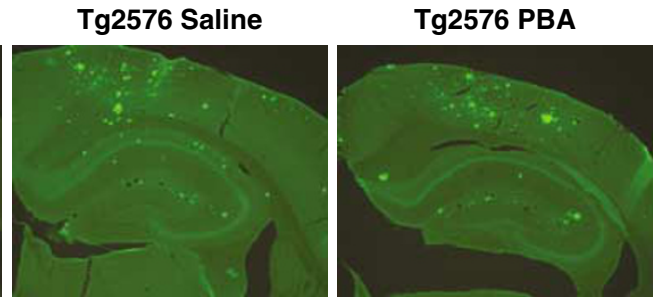

Figure 2 4-PBA treatment does not affect $A \beta$ levels in 16-month-old Tg2576 transgenic mice. (a) A $\beta_{42}$ and A $\beta_{40}$ determined by ELISA in Tg2576 mice treated with saline or 4-PBA showed similar values (mean \pm SEM of five individual determinations). (b) Multiple extracellular deposits stained with 6 E I0 antiserum were detected in both saline- and PBA-treated Tg2576 mice. Amyloid deposits were absent in age-matched control non-transgenic (Non-Tg) mice. Representative brain sections of Non-Tg, saline-, and 4-PBA-treated Tg2576 mice are shown. Scale bar $=100 \mu \mathrm{m}$.
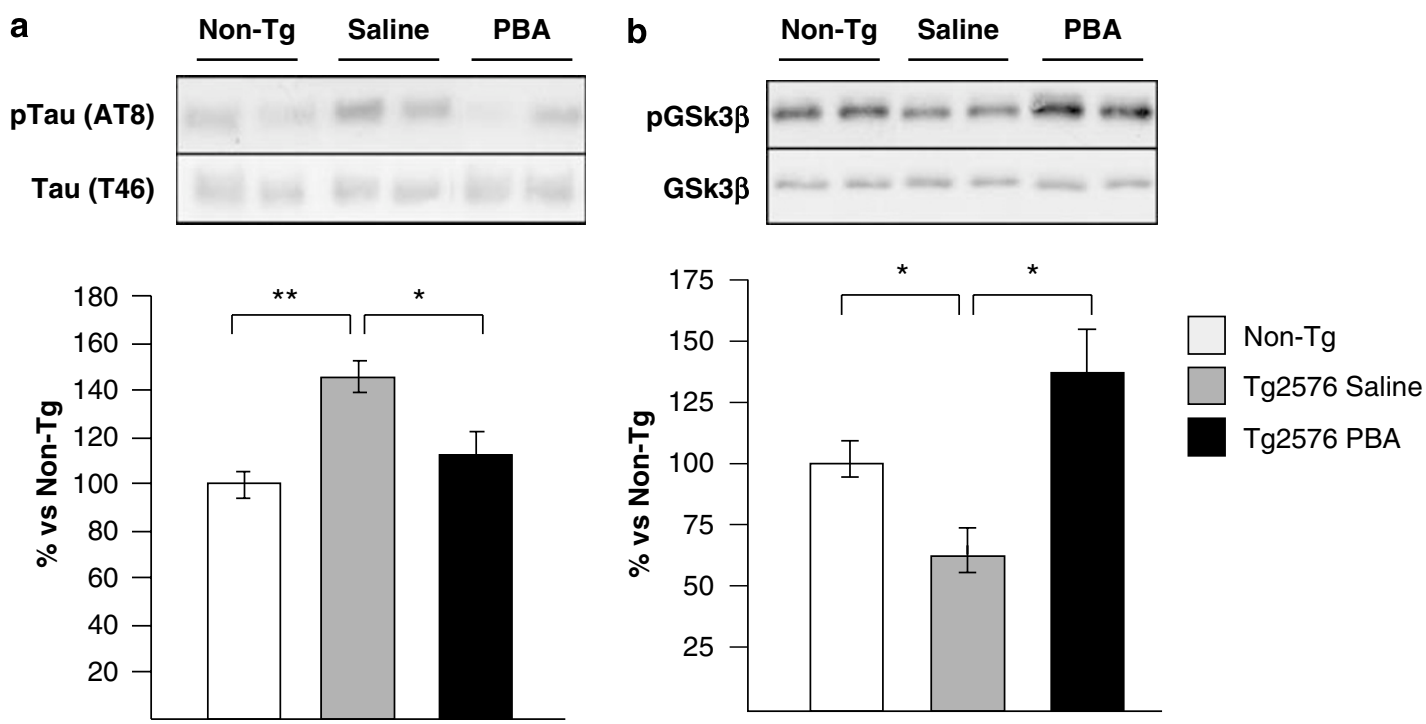

Figure 3 4-PBA regulates tau phosphorylation through the pGSK3 $\beta$ pathway in Tg2576 transgenic mice. (a) Western blot analysis using a phosphospecific antibody, AT8, normalized to total tau (T46) showed that tau was hyperphosphorylated in the hippocampus of I6-month-old saline-treated Tg2576 mice compared with non-transgenic (Non- $\mathrm{Tg}, * * p<0.01$ ) and to 4-PBA-treated mice $(* p<0.05)$. Bars represent the densitometric analysis of five to six individual determinations. Data are expressed as a mean percentage ( \pm SEM) vs Non-Tg mice (I00\%). (b) pGSK3 $\beta$-Ser9 levels normalized to GSK3 $\beta$ total protein were significantly decreased in saline-treated Tg2576 mice compared with Non-Tg mice $(* p<0.05)$. This decrease was inverted after 4-PBA treatment. Bars represent the densitometric analysis of five to six individual determinations. Data are expressed as mean percentage ( \pm SEM) vs Non-Tg mice (I00\%).

been recently implicated in synaptic plasticity and learning behavior. Therefore, we speculated that 4-PBA, through inhibition of HDAC, might induce a transcriptional modification leading to activation of plasticity genes. To assess whether histone acetylation could play a role in memory formation in Tg2576 transgenic mice, we analyzed the levels of acetylation of histone $4(\mathrm{AcH} 4)$ and histone 3 $(\mathrm{AcH} 3)$ in frontal cortex protein lysates obtained from 16-month-old Tg2576 mice and non-transgenic controls. As depicted in Figure $4 \mathrm{a}$, a one-way ANOVA showed a significant group effect $\left(\mathrm{F}_{(2,11)}=13.0 ; p<0.001\right)$ in $\mathrm{AcH} 4$ levels. Scheffe's multiple-comparison test revealed that 16-month-old Tg2576 mice showed a robust decrease in AcH4 levels $\left(35.2 \pm 6.0 \%,{ }^{* *} p<0.01\right)$ compared with agematched control mice $(100.8 \pm 8.0 \%)$ that were nearly restored after 4 -PBA treatment $\left(70.7 \pm 12.3 \%,{ }^{* *} p<0.01\right.$ vs saline-treated Tg2576 mice) (Figure 4a).

Next, we used immunohistochemistry to examine the effect of the treatment on hippocampal AcH4 signal compared with a neuronal nuclei marker (NeuN) distribution. Similar immunoreactivity patterns were found in hippocampus for NeuN and $\mathrm{AcH} 4$ in 
a

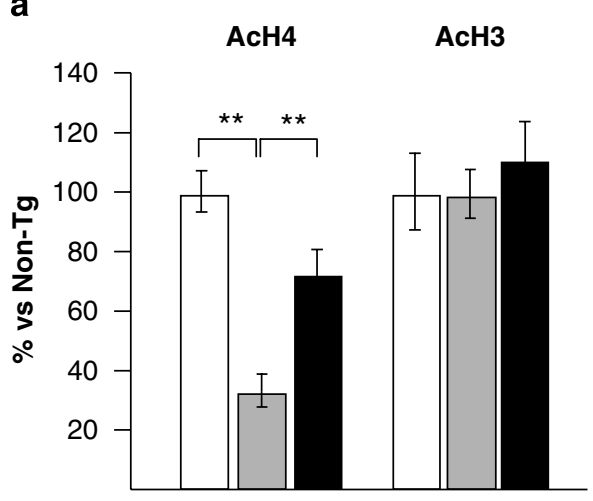

b

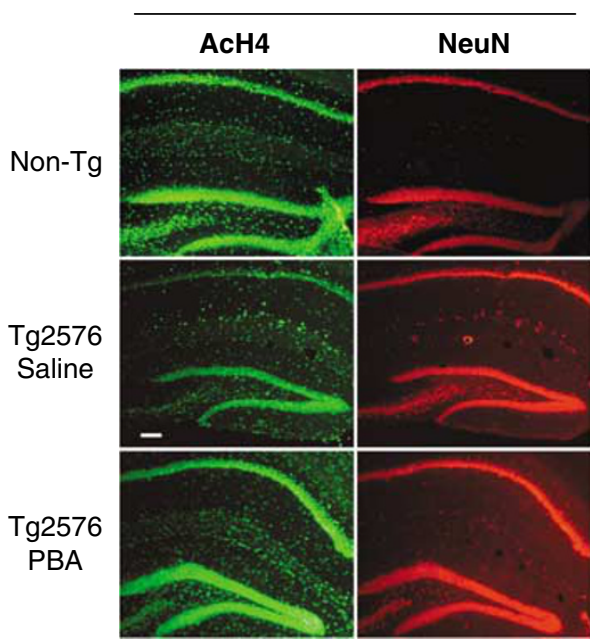

C

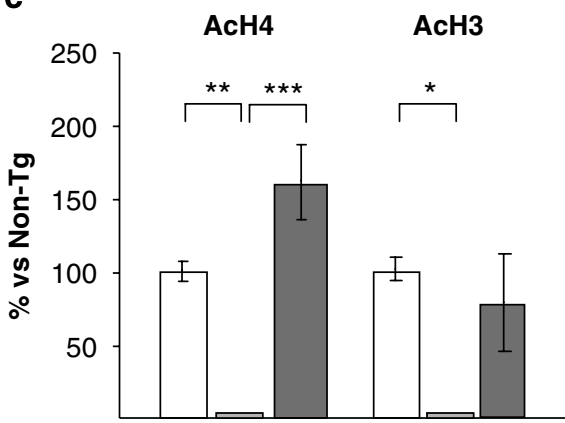

Non-Tg

Tg2576 Saline

Tg2576 PBA

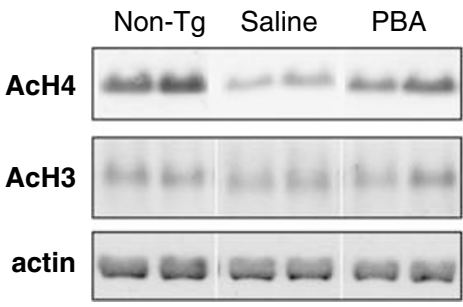

CA3

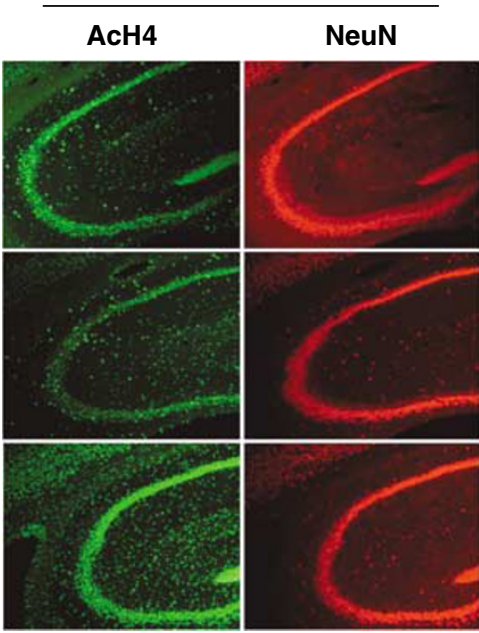

Non-Tg

$\operatorname{Tg} 2576$

Tg2576 PBA

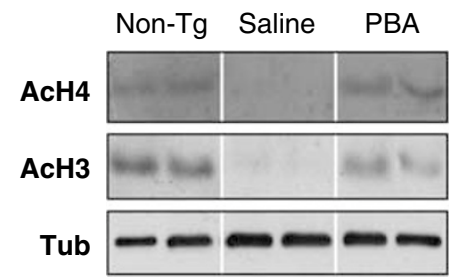

Figure 4 The drop-off of histone acetylation observed in 16-month-old Tg2576 mice brain was ameliorated after 4-PBA treatment. (a) Western blot analysis showed a decreased acetylation of histone $4(\mathrm{AcH} 4)$ in cerebral cortex lysates obtained from I6-month-old Tg2576 mice compared with nontransgenic controls (Non-Tg) (** $<<0.0$ I). This decrease was attenuated in Tg2576 transgenic mice treated with 4-PBA (** $p<0.01$ vs saline-treated Tg2576 mice). No difference was observed in $\mathrm{H} 3$ acetylation $(\mathrm{AcH} 3)$ in the same extracts. Staining for actin was used for normalization of $\mathrm{AcH} 4$ and $\mathrm{AcH} 3$ values. Bars represent the densitometric analysis of five to six individual determinations. Data are expressed as mean percentage ( \pm SEM) vs Non-Tg mice (I 00\%). (b) Representative images showing $\mathrm{AcH} 4$ and NeuN immunoreactivity (IR) in the CAI, CA3, and dentate gyrus of I6-month-old non-transgenic mice compared with saline and PBA-treated Tg2576 mice. Compared with non-transgenic, saline-treated Tg2576 mice showed a significant decrease in the number of AcH4-positive cells in CAI and CA3 areas. In contrast, PBA-treated Tg2576 mice showed a similar IR pattern to non-transgenic mice. Scale bar $=100 \mu \mathrm{m}$. (c) Western blot analysis showed a massive drop off in acetylation of $\mathrm{H} 4$ and $\mathrm{H} 3$ in primary hippocampal cultures from Tg2576 mice that was reversed after 4 days of treatment with 4-PBA $(2 \mathrm{mM})(* p<0.05$, *** $p<0.01$, **** $p<0.00$ I vs Tg2576 primary neurons). Staining for tubulin (Tub) was used for normalization of $\mathrm{AcH} 4$ and $\mathrm{AcH} 3$ values. Bars represent the densitometric analysis of four cultures. Data are expressed as a mean percentage $( \pm \mathrm{SEM})$ vs Non-Tg primary neurons.

non-transgenic mice. As depicted in Figure 4b, levels of $\mathrm{AcH} 4$ were decreased in $\mathrm{CA} 1$ and $\mathrm{CA} 3$ neuronal population in Tg2576 saline-treated mice. An increased number of AcH4-immunopositive neurons was observed in CA1 and $\mathrm{CA} 3$ regions in transgenic mice that received 4-PBA treatment compared with transgenic mice treated with saline. These results suggest that 4-PBA treatment, by increasing neuronal AcH4, improved the capability to induce changes in the expression of learning and memory-related genes. 
We further supported this finding by using primary hippocampal culture extracts treated with 4-PBA (as explained above). We found a drastic decrease in $\mathrm{AcH} 4$ and AcH3 levels $\left({ }^{* *} p<0.01\right)$ in $\mathrm{Tg} 2576$ compared with control non-transgenic neurons (Figure $4 \mathrm{c}$ ). In addition, in Tg2576 neurons treated with 4-PBA, the levels of AcH4 and $\mathrm{AcH} 3$ underwent a robust increase compared with the Tg2576 control neurons, which confirm the results observed in vivo. This modification in histone acetylation, through the regulation of chromatin remodeling, can underpin the recovery of spatial memories observed with the treatment.

\section{Synaptic Plasticity Markers}

An increase in AcH4 is most likely to regulate relatively specific transcriptional programs. AMPA receptor trafficking at the postsynaptic membrane underlines rapid transmission and synaptic plasticity. It has been described that a synaptic loss of the AMPA receptor subunit GluR1 and the postsynaptic density protein 95 (PSD95) in the Tg2576 mice might be related to their memory impairment. We investigated whether the expression levels of these synaptic markers underwent modification after 4-PBA treatment (Figure 5a). A one-way ANOVA showed a significant group effect $\left(\mathrm{F}_{(2,24)}=13.1 ; p<0.001\right)$. Scheffe's multiple-comparison test showed that 4-PBA induced a robust increase $(170.2 \pm 16.9 \%)$ in the AMPA receptor subunit GluR1 expression level in membrane-enriched hippocampal protein extracts in the group of transgenic mice after 4-PBA treatment compared with the vehicletreated group $\left(78.3 \pm 7.3 \% ;{ }^{*} p<0.01\right)$ and with the nontransgenic group $(100.0 \pm 12.5 \%)$. The same membranes were stained for PSD95. As depicted in Figure 5a, a one-way ANOVA showed a significant group effect $\left(\mathrm{F}_{(2,24)}=8.5\right.$; $p<0.01)$. Scheffe's multiple-comparison test showed that 4-PBA increased (120.2 $\pm 3.3 \%)$ PSD95 expression level in membrane-enriched protein hippocampal extracts in the group of transgenic mice after 4-PBA treatment compared with the vehicle-treated group $\left(79.6 \pm 6.3 \%,{ }^{* *} p<0.01\right)$.

The microtubule-associated protein-2 (MAP-2) is a protein localized primarily in neuronal dendrites. MAP-2 expression coincides with dendritic outgrowth, branching, and post-lesion dendritic remodeling, suggesting that this protein plays a crucial role in plasticity (Johnson and Jope, 1992). We performed quantitative western blot analysis to measure MAP-2, and we found that MAP-2 expression levels are significantly decreased in $\mathrm{Tg} 2576$ mice $(54.9 \pm 10.7, p<0.05)$ compared with non-transgenic mice $(100.0 \pm 14.9)$ and it is partially restored after PBA treatment (77.7 \pm 11.6 , Figure 5a). Next, we used immunohistochemistry to examine the distribution of MAP-2 and, as depicted in Figure 5b, we observed a significant increase in hippocampal MAP-2 immunoreactivity in the hippocampus of 4-PBA-treated mice compared with saline-treated Tg2576 mice, which confirms the western blot data and suggests that decreased MAP-2 correlates with reduced capability of learning and memory.

a

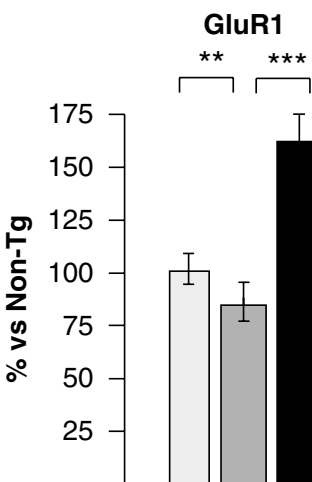

b

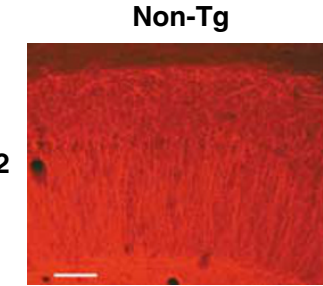

PSD95

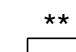

MAP2

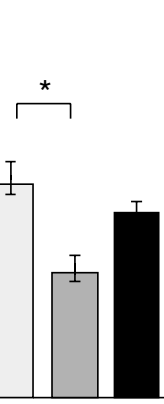

Tg2576 Saline
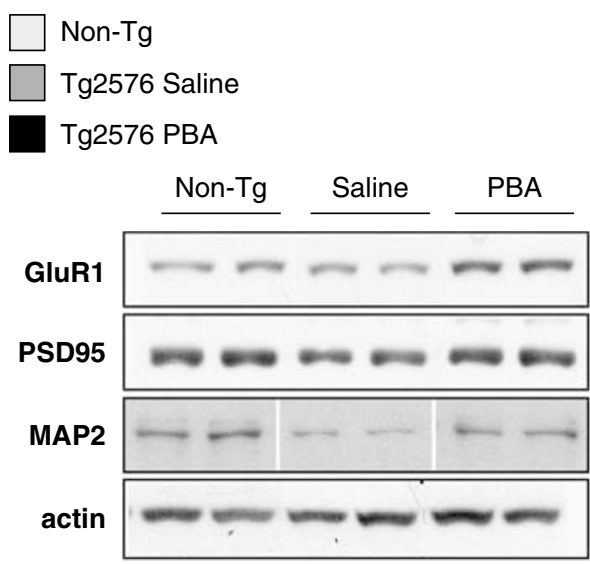

Tg2576 PBA
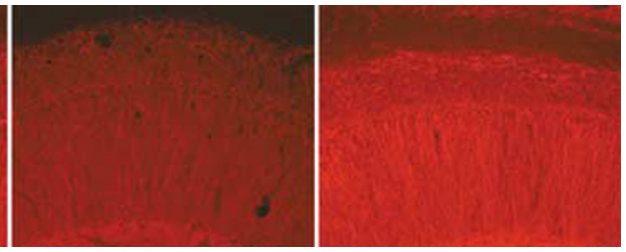

Figure 5 4-PBA treatment enhances the expression of synaptic plasticity markers. (a) Western blot analysis confirmed that the AMPA receptor subunit GluRI and the postsynaptic density protein 95 (PSD95) protein levels were decreased in membrane-enriched hippocampal protein extracts obtained from 16-month-old Tg2576 mice compared with non-transgenic (Non-Tg) mice $\left.{ }^{*} p<0.05\right)$. Treatment with 4-PBA significantly increased AMPA receptor subunit GluRI protein level compared with Non-Tg mice and restored PSD95 protein level (*** $p<0.00$ I and $* *$ p $<0.0$ I vs saline-treated Tg2576 mice). Staining for actin was used for normalization of GluRI and PSD95 values. Bars represent the densitometric analysis of five individual determinations. Data are expressed as a mean percentage ( \pm SEM) vs Non-Tg mice. (b) Representative images showing decreased MAP-2 immunoreactivity (IR) in the hippocampus of 16-month-old Tg2576 mice compared with Non-Tg mice. Tg2576 mice treated with 4-PBA showed significantly increased MAP-2 IR compared with Tg2576-saline-treated mice. Representative brain sections of Non-Tg, saline- and 4-PBA-treated Tg2576 mice are shown. Scale bar $=50 \mu \mathrm{m}$. 


\section{ChIP Assays}

To provide evidence for a more direct relationship between changes in histone acetylation and the increase in synaptic plasticity markers, we tested the effect of PBA on histone 4 (H4) acetylation at the promoter region of the AMPA receptor GluR1 subunit using ChIP assay. We analyzed histone modifications in transgenic mice brain 5 weeks after 4-PBA or saline administration. We performed ChIP assays with antibody against $\mathrm{AcH} 4$ and quantified the amount of DNA associated with the AcH4 using real-time PCR. $C_{\mathrm{t}}$ values of immunoprecipitated samples were normalized to $C_{\mathrm{t}}$ values obtained from 'input' or total DNA, at which there is no difference between 4-PBA and saline samples as expected (Figure 6a). To control for the specificity of antibody binding, we immunoprecipitated samples with IgG, which precipitated negligible levels of the studied genes (data not show). An increased association of $\mathrm{AcH} 4$ at the AMPA receptor GluR1 subunit promoter was evident following 4-PBA treatment compared with saline treatment (fold change: $4.16 \pm 0.9, p<0.05$ ). There were no significant
$\mathrm{AcH} 4$ changes at the $\mathrm{B} 2 \mathrm{~m}$ promoter, used as a housekeeping gene (Figure 6b).

\section{DISCUSSION}

This study was designed to analyze the potential beneficial role of 4-PBA in cognitive impairment and neuropathology related to $A D$. In our study, we found that treatment of 16-month-old Tg2576 mice with 4-PBA during 5 weeks reversed spatial reference memory deficit. This beneficial effect of 4-PBA was independent of the $\mathrm{A} \beta$ peptide content in the brain, because $\mathrm{A} \beta_{42}$ and $\mathrm{A} \beta_{40}$ levels and senile plaques were unaffected in Tg2576 mice after the treatment. 4-PBA increased the acetylation of histones, which induced elevated levels of marker proteins for synaptic integrity and plasticity that could lead to the recovery of long-term spatial memories. 4-PBA-treated transgenic mice showed a significant decrease in phosphorylated tau in the hippocampus, which may result from GSK3 $\beta$ inhibition. Importantly, 4-PBA, has few side effects, is safe for patients and can

a

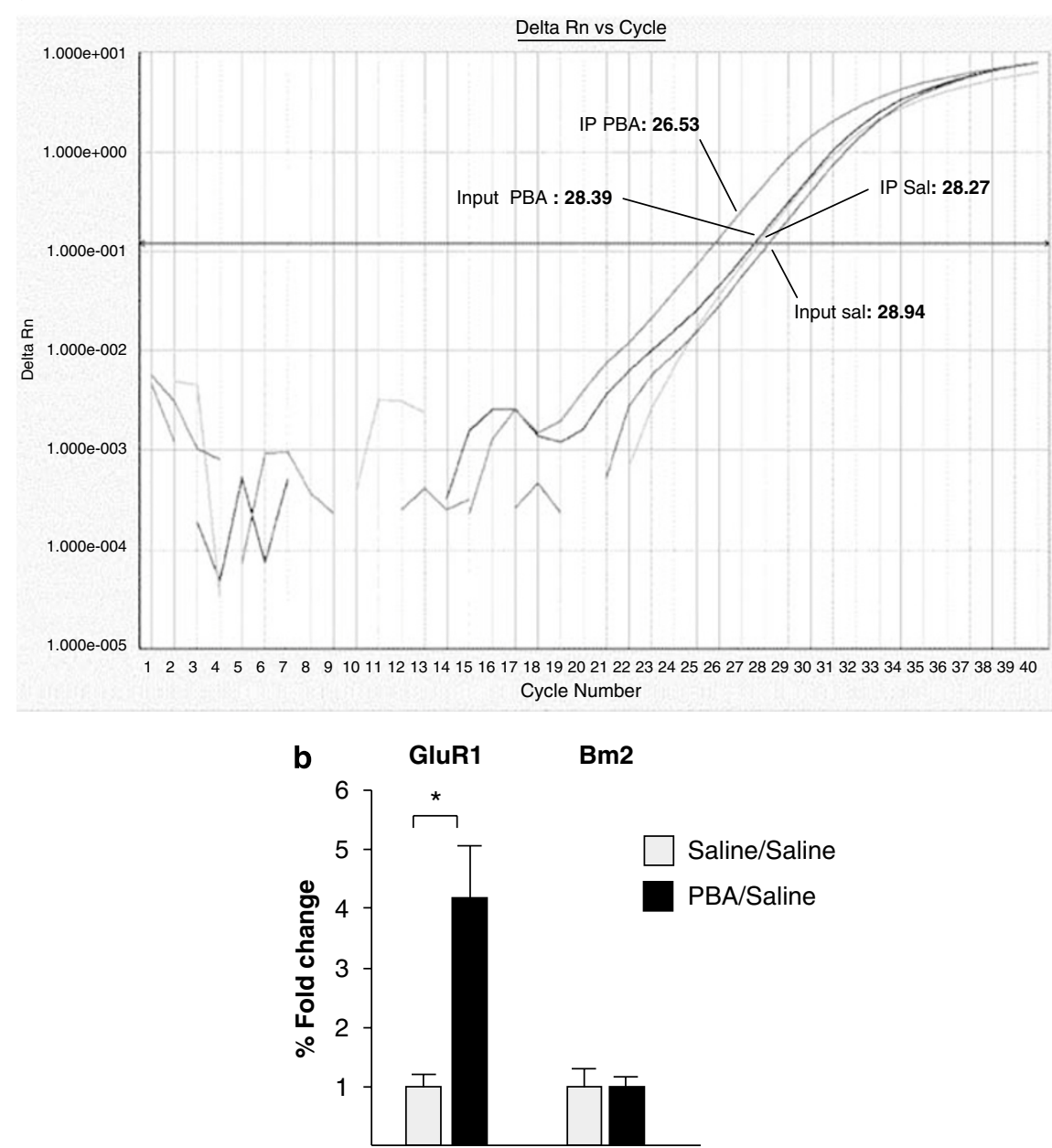

Figure 6 Chromatin immunoprecipitation showed that histone $4(\mathrm{H} 4)$ acetylation is selectively increased at the AMPA receptor GluRI subunit gene promoter in Tg2576 mice after 4-PBA treatment compared with saline-treated animals. (a) Levels of acetylated H4 at the AMPA receptor GluRI subunit promoter were quantified using real-time PCR by comparing relative $C_{t}$ values. $C_{t}$ values of immunoprecipitated DNA were normalized to $C_{t}$ values obtained from the 'input' genomic DNA, at which there is no difference between 4-PBA and saline samples. Representative plot is shown. (b) Comparison of these $C_{t}$ values (4-PBA vs saline-treated samples) showed a significant fold increase in levels of H4 acetylation at the AMPA receptor GluRI subunit in Tg2576 mice after 4-PBA treatment compared with saline-treated animals. 
penetrate well into cerebrospinal fluid (Berg et al, 2001); therefore, the findings in this study suggest a great potential role for 4-PBA as a therapeutic agent to restore memory function in $\mathrm{AD}$.

Tg2576 mice show rapid increases in $\mathrm{A} \beta$ starting at 6 months and also show spatial memory impairment by $9-10$ months of age. A 14-fold increase in $\mathrm{A} \beta_{42}$ and numerous $\mathrm{A} \beta$ plaques accompany the appearance of these behavioral deficits (Hsiao et al, 1996). Here, in Tg2576 mice treated with 4-PBA, we found that memory deficits were markedly ameliorated without any alteration in cortical $\mathrm{A} \beta$ levels and senile plaques, suggesting that 4-PBA does not interfere with $\mathrm{A} \beta$ production to produce its beneficial effects on learning and memory. Earlier studies have shown that improved learning and memory performance is not always associated with any detectable alteration in brain $\mathrm{A} \beta$ burden (Dodart et al, 2002; Gong et al, 2004; Malm et al, 2007, Green et al, 2008), suggesting that the relationship between soluble and insoluble brain $\mathrm{A} \beta$ concentrations and memory impairment in transgenic mice is task specific and complex. In addition, in extensive studies, no clear correlation between deposited forms of $\mathrm{A} \beta$ (such as plaques) and memory impairment in $\mathrm{AD}$ patients has been shown (Hyman et al, 1984; Braak and Braak, 1991). In fact, recent reports suggest that soluble $\mathrm{A} \beta$ may be better correlated to both neurodegeneration and memory impairment (Lue et al, 1999; McLean et al, 1999; Lesné et al, 2008).

The 'GSK3 hypothesis of AD' proposes GSK3 $\beta$ as a causal mediator of $\mathrm{AD}$, as its dysregulation involves the hyperphosphorylation of tau and memory impairment (review by Hooper et al, 2008). An increase in tau phosphorylation level at Ser202/Thr205 (AT8 site) was observed in the hippocampus of Tg2576 mice treated with saline. Phosphotau is an integral component of the NFT deposits that disrupt neuronal function, and it is possible that dysregulation of tau phosphorylation in the hippocampus can be translated into a memory impairment in the development of synaptic dysfunction such as AD (Arendt et al, 2003; Ikeda et al, 2007). Here, we found that phospho-tau levels did not differ between the transgenic 4-PBA-treated mice and the non-transgenic mice. This is consonant with recent observations suggesting the beneficial effects of reducing tau to prevent behavioral deficits in $\mathrm{AD}$ transgenic mice without altering their high $\mathrm{A} \beta$ levels (Roberson et al, 2007; Green et al, 2008). Thus, our findings also indicate that phospho-tau reduction could protect against $\mathrm{A} \beta$ and improve cognition in mice.

Importantly, it has been shown that GSK $3 \alpha / \beta$ plays a central role in signaling downstream effects of endoplasmic reticulum (ER) stress (Kim et al, 2005). ER stress is involved in the pathogenesis of several diseases including $\mathrm{AD}$, whose pathological hallmarks are related to deposits of aggregated proteins. Various types of cellular stress cause accumulation of misfolded proteins in the ER lumen, resulting in ER stress. ER stress activates GSK3 $\beta$ through dephosphorylation of Ser9 (Song et al, 2002). 4-PBA has been shown to act as a chemical chaperone reversing the mislocalization and/ or aggregation of proteins associated with human diseases (Rubenstein and Zeitlin, 2000; Kubota et al, 2006). It has been described that valproate, another chemical chaperone, protects cells from ER stress, at least in part by inhibiting GSK3 $\beta$ (Kim et al, 2005). It has been shown that PBA suppressed ER-mediated apoptosis by inhibiting eukaryotic initiation factor $2 \alpha$ phosphorylation (eIF2 $\alpha$ ), CCAAT/ enhancer-binding protein homologous protein induction, and caspase-12 activation (Qi et al, 2004). We (data not mentioned in the paper) have found that 4-PBA attenuates the increase in the phosphorylation eIF $2 \alpha$ and the decrease in the ER chaperone, glucose-regulated protein (GRP78) in Tg2576 mice, measures related to the ER-stress. We propose that 4-PBA protects neurons from ER stress and inhibits GSK3 $\beta$, which prevents tau phosphorylation and restores neuronal plasticity.

We found that Tg2576 mice exhibit a decrease in AcH4 in brain areas related to memory functions (hippocampus and cortex), which could be related to a tightly packed chromatin structure corresponding to transcriptional repression. Gene expression has been shown to underlie longterm memory formation in several vertebrate and invertebrate species, probably through the formation of new synaptic connections (Tully et al, 2003). It is most likely that both the formation of new synapses and the consolidation of old ones, which require new protein synthesis, are interrupted in $\operatorname{Tg} 2576$ transgenic mice because of an indirect transcriptional repression.

Gene transcription requires the activation of transcription factors, but also the induction of dynamic changes in the organization of chromatin directing gene expression. It has been shown that histone acetylation is necessary for high levels of transcription, and, moreover, histone acetylation controls transcription of genes required for consolidation of long-term memories and LTP (Bailey et al, 2004, Levenson and Sweatt 2005; Fischer et al, 2007). Aberrant histone acetyl transferase and HDAC activity may also be a common underlying mechanism contributing to neurodegeneration during neurological diseases, including stroke, Huntington's disease, ALS, Friedreich ataxia, and Alzheimer's disease (review by Langley et al, 2005). Some studies have shown that transcription is indeed dysregulated in some brain regions in association with disease progression and support the notion of a common mechanism of disruption of RNA transcription in some neurodegenerative disorders (Anderson et al, 2008). Recently, some studies suggest the use of HDAC inhibitors as therapy to restore histone acetylation and transcriptional activation in different neurodegenerative models (review by Abel and Zukin, 2008; Hahnen et al, 2008; Kazantsev and Thompson, 2008).

AMPA receptor GluR1 subunit, PSD95, and MAP-2 are plasticity markers with crucial importance in synapse formation and function. Postsynaptic deficits of PSD95, GluR1, and MAP-2 described in brains from AD patients and Tg2576 mice (Almeida et al, 2005; Fonseca et al, 2004; Liu et al, 2005) may contribute to synaptic dysfunction with resultant impaired learning. In agreement with that, we observed reduced expression of AMPA receptor subunit GluR1, PSD95, and MAP-2 in Tg2576 hippocampus that may contribute to poor performance in the water maze. 4-PBA-treated mice showed a restoration of these markers, which correlates with the improvement in the cognitive functions. Several studies have already shown that 4-PBA can induce a variety of gene alterations that increase survival and prevent neurotoxicity in different models (Chang and Min, 2002; Kang et al, 2002; Ryu et al, 2005). We provide evidence that the transcriptional regulation in 
response to 4-PBA treatment by inducing acetylation of histones, results in the upregulation of downstream synaptic plasticity markers and contributes to the recovery in learning and memory.

The results herein presented support the hypothesis that 4-PBA, by inducing hyperacetylation of histones, reduces tau pathology and activates the synthesis of proteins essential for synaptic plasticity, leading to a correct hippocampal function and a reversal of memory impairment. Altogether, according to the present findings, we propose that PBA, a drug already approved for clinical use, may also represent a particularly promising therapeutic tool for the treatment of AD.

\section{ACKNOWLEDGEMENTS}

This study has been supported by the Ministry of Education and Science (SAF2005-05086, SAF2008-02342), Ministry of Health (CIBERNED), and UTE project FIMA, Spain. We thank Fabian Arenas, Edurne Barba, María Espelosín, and Sergio María for technical help, and the animal facility of CIMA for technical support.

\section{DISCLOSURE/CONFLICT OF INTEREST}

The authors declare that, except for income received from our primary employer, no financial support or compensation has been received from any individual or corporate entity over the past 3 years for research or professional service and that there are no personal financial holdings that could be perceived as constituting a potential conflict of interest.

\section{REFERENCES}

Abel T, Kandel E (1998). Positive and negative regulatory mechanisms that mediate long-term memory storage. Brain Res Brain Res Rev 26: 360-378.

Abel T, Zukin RS (2008). Epigenetic targets of HDAC inhibition in neurodegenerative and psychiatric disorders. Curr Opin Pharmacol 8: 57-64.

Almeida CG, Tampellini D, Takahashi RH, Greengard P, Lin MT, Snyder EM et al (2005). Beta-amyloid accumulation in APP mutant neurons reduces PSD-95 and GluR1 in synapses. Neurobiol Dis 20: 187-198.

Anderson AN, Roncaroli F, Hodges A, Deprez M, Turkheimer FE (2008). Chromosomal profiles of gene expression in Huntington's disease. Brain 131: 381-388.

Arendt T, Stieler J, Strijkstra AM, Hut RA, Rudiger J, Van der Zee EA et al (2003). Reversible paired helical filament-like phosphorylation of tau is an adaptive process associated with neuronal plasticity in hibernating animals. J Neurosci 23: 6972-6981.

Bailey CH, Kandel ER, Si K (2004). The persistence of long-term memory: a molecular approach to self-sustaining changes in learning-induced synaptic growth. Neuron 44: 49-57.

Berg S, Serabe B, Aleksic A, Bomgaars L, McGuffey L, Dauser R et al (2001). Pharmacokinetics and cerebrospinal fluid penetration of phenylacetate and phenylbutyrate in the nonhuman primate. Cancer Chemother Pharmacol 47: 385-390.

Braak H, Braak E (1991). Neuropathological stageing of Alzheimerrelated changes. Acta Neuropathol 82: 239-259.
Bredy TW, Barad M (2008). The histone deacetylase inhibitor valproic acid enhances acquisition, extinction, and reconsolidation of conditioned fear. Learn Mem 15: 39-45.

Brusilow SW, Maestri NE (1996). Urea cycle disorders: diagnosis, pathophysiology, and therapy. Adv Pediatr 43: 127-170.

Chang JG, Hsieh-Li HM, Jong YJ, Wang NM, Tsai CH, Li H (2001). Treatment of spinal muscular atrophy by sodium butyrate. Proc Natl Acad Sci USA 98: 9808-9813.

Chang KT, Min KT (2002). Regulation of lifespan by histone deacetylase. Ageing Res Rev 1: 313-326.

Collins AF, Pearson HA, Giardina P, McDonagh KT, Brusilow SW, Dover GJ (1995). Oral sodium phenylbutyrate therapy in homozygous beta thalassemia: a clinical trial. Blood 85: 43-49.

Cremer JE, Lai JC, Sarna GS (1977). Rapid blood brain transport and metabolism of butyrate and pyruvate in the rat after portocaval anastomosis. J Physiol 266: 70-71.

Cummings JL, Cole G (2002). Alzheimer disease. JAMA 287: 2335-2338.

Dodart JC, Bales KR, Gannon KS, Greene SJ, DeMattos RB, Mathis $C$ et al (2002). Immunization reverses memory deficits without reducing brain Abeta burden in Alzheimer's disease model. Nat Neurosci 5: 452-457.

Dunah AW, Wang Y, Yasuda RP, Kameyama K, Huganir RL, Wolfe $\mathrm{BB}$ et al (2000). Alterations in subunit expression, composition, and phosphorylation of striatal $N$-methyl-D-aspartate glutamate receptors in a rat 6-hydroxydopamine model of Parkinson's disease. Mol Pharmacol 57: 342-352.

Ferrante RJ, Kubilus JK, Lee J, Ryu H, Beesen A, Zucker B et al (2003). Histone deacetylase inhibition by sodium butyrate chemotherapy ameliorates the neurodegenerative phenotype in Huntington's disease mice. J Neurosci 23: 9418-9427.

Fischer A, Sananbenesi F, Wang X, Dobbin M, Tsai LH (2007). Recovery of learning and memory is associated with chromatin remodelling. Nature 447: 178-182.

Fonseca MI, Zhou J, Botto M, Tenner AJ (2004). Absence of C1q leads to less neuropathology in transgenic mouse models of Alzheimer's disease. J Neurosci 24: 6457-6465.

Fontán-Lozano A, Romero-Granados R, Troncoso J, Múnera A, Delgado-García JM, Carrión AM (2008). Histone deacetylase inhibitors improve learning consolidation in young and in KAinduced-neurodegeneration and SAMP-8-mutant mice. Mol Cell Neurosci 39: 193-201.

Gardian G, Browne SE, Choi DK, Klivenyi P, Gregorio J, Kubilus JK et al (2005). Neuroprotective effects of phenylbutyrate in the N171-82Q transgenic mouse model of Huntington's disease. J Biol Chem 280: 556-563.

Gardian G, Yang L, Cleren C, Calingasan NY, Klivenyi P, Beal MF (2004). Neuroprotective effects of phenylbutyrate against MPTP neurotoxicity. Neuromolecular Med 5: 235-241.

Gerlai R (2001). Behavioral tests of hippocampal function: simple paradigms complex problems. Behav Brain Res 125: 269-277.

Gong B, Vitolo OV, Trinchese F, Liu S, Shelanski M, Arancio O (2004). Persistent improvement in synaptic and cognitive functions in an Alzheimer mouse model after rolipram treatment. J Clin Invest 114: 1624-1634.

Green KN, Steffan JS, Martinez-Coria H, Sun X, Schreiber SS, Thompson LM et al (2008). Nicotinamide restores cognition in Alzheimer's disease transgenic mice via a mechanism involving sirtuin inhibition and selective reduction of Thr231-phosphotau. J Neurosci 28: 11500-11510.

Hahnen E, Hauke J, Tränkle C, Eyüpoglu IY, Wirth B, Blümcke I (2008). Histone deacetylase inhibitors: possible implications for neurodegenerative disorders. Expert Opin Investig Drugs 17: $169-184$.

Hardy J (2006). A hundred years of Alzheimer's disease research. Neuron 52: 3-13.

Hooper C, Killick R, Lovestone S (2008). The GSK3 hypothesis of Alzheimer's disease. J Neurochem 104: 1433-1439. 
Hsiao K, Chapman P, Nilsen S, Eckman C, Harigaya Y, Younkin S et al (1996). Correlative memory deficits, Abeta elevation, and amyloid plaques in transgenic mice. Science 274: 99-102.

Huang Y, Doherty JJ, Dingledine R (2002). Altered histone acetylation at glutamate receptor 2 and brain-derived neurotrophic factor genes is an early event triggered by status epilepticus. J Neurosci 22: 8422-8428.

Hyman BT, Van Hoesen GW, Damasio AR, Barnes CL (1984). Alzheimer's disease: cell-specific pathology isolates the hippocampal formation. Science 225: 1168-1170.

Ikeda Y, Ishiguro K, Fujita SC (2007). Ether stress-induced Alzheimer-like tau phosphorylation in the normal mouse brain. FEBS Lett 581: 891-897.

Johnson GV, Jope RS (1992). The role of microtubule-associated protein 2 (MAP-2) in neuronal growth, plasticity, and degeneration. J Neurosci Res 33: 505-512.

Kang HL, Benzer S, Min KT (2002). Life extension in Drosophila by feeding a drug. Proc Natl Acad Sci USA 99: 838-843.

Kazantsev AG, Thompson LM (2008). Therapeutic application of histone deacetylase inhibitors for central nervous system disorders. Nat Rev Drug Discov 7: 854-868.

Kim AJ, Shi Y, Austin RC, Werstuck GH (2005). Valproate protects cells from ER stress-induced lipid accumulation and apoptosis by inhibiting glycogen synthase kinase-3. J Cell Sci 118: 89-99.

Kubota K, Niinuma Y, Kaneko M, Okuma Y, Sugai M, Omura T et al (2006). Suppressive effects of 4-phenylbutyrate on the aggregation of Pael receptors and endoplasmic reticulum stress. J Neurochem 97: 1259-1268.

Langley B, Gensert JM, Beal MF, Ratan RR (2005). Remodeling chromatin and stress resistance in the central nervous system: histone deacetylase inhibitors as novel and broadly effective neuroprotective agents. Curr Drug Targets CNS Neurol Disord 4: 41-50.

Lesné S, Kotilinek L, Ashe KH (2008). Plaque-bearing mice with reduced levels of oligomeric amyloid-beta assemblies have intact memory function. Neuroscience 151: 745-749.

Levenson JM, O'Riordan KJ, Brown KD, Trinh MA, Molfese DL, Sweatt JD (2004). Regulation of histone acetylation during memory formation in the hippocampus. J Biol Chem 279: 40545-40559.

Levenson JM, Sweatt JD (2005). Epigenetic mechanisms in memory formation. Nat Rev Neurosci 6: 108-118.

Liu HX, Zhang JJ, Zheng P, Zhang Y (2005). Altered expression of MAP-2, GAP-43, and synaptophysin in the hippocampus of rats with chronic cerebral hypoperfusion correlates with cognitive impairment. Brain Res Mol Brain Res 139: 169-177.

Livak KJ, Schmittgen TD (2001). Analysis of relative gene expression data using real-time quantitative PCR and the 2 (-Delta Delta C(T)). Methods 25: 402-408.

Lue LF, Kuo YM, Roher AE, Brachova L, Shen Y, Sue L et al (1999). Soluble amyloid beta peptide concentration as a predictor of synaptic change in Alzheimer's disease. Am J Pathol 155: 853-862.

Malm TM, Iivonen H, Goldsteins G, Keksa-Goldsteine V, Ahtoniemi T, Kanninen K et al (2007). Pyrrolidine dithiocarba- mate activates Akt and improves spatial learning in APP/PS1 mice without affecting beta-amyloid burden. J Neurosci 27: 3712-3721.

Mandelkow EM, Biernat J, Drewes G, Gustke N, Trinczek B, Mandelkow E (1995). Tau domains, phosphorylation, and interactions with microtubules. Neurobiol Aging 16: 355-363.

Mandelkow EM, Drewes G, Biernat J, Gustke N, Van Lint J, Vandenheede JR et al (1992). Glycogen synthase kinase-3 and the Alzheimer-like state of microtubule-associated protein tau. FEBS Lett 314: 315-321.

McLean CA, Cherny RA, Fraser FW, Fuller SJ, Smith MJ, Beyreuther $\mathrm{K}$ et al (1999). Soluble pool of Abeta amyloid as a determinant of severity of neurodegeneration in Alzheimer's disease. Ann Neurol 46: 860-866.

Minamiyama M, Katsuno M, Adachi H, Waza M, Sang C, Kobayashi Y et al (2004). Sodium butyrate ameliorates phenotypic expression in a transgenic mouse model of spinal and bulbar muscular atrophy. Hum Mol Genet 13: 1183-1192.

Qi X, Hosoi T, Okuma Y, Kaneko M, Nomura Y (2004). Sodium 4phenylbutyrate protects against cerebral ischemic injury. $\mathrm{Mol}$ Pharmacol 66: 899-908.

Ribé EM, Pérez M, Puig B, Gich I, Lim F, Cuadrado M et al (2005). Accelerated amyloid deposition, neurofibrillary degeneration and neuronal loss in double mutant APP/tau transgenic mice. Neurobiol Dis 20: 814-822.

Roberson ED, Scearce-Levie K, Palop JJ, Yan F, Cheng IH, Wu T et al (2007). Reducing endogenous tau ameliorates amyloid betainduced deficits in an Alzheimer's disease mouse model. Science 316: $750-754$.

Rubenstein RC, Zeitlin PL (2000). Sodium 4-phenylbutyrate downregulates Hsc70: implications for intracellular trafficking of DeltaF508-CFTR. Am J Physiol Cell Physiol 278: 259-267.

Ryu H, Smith K, Camelo SI, Carreras I, Lee J, Iglesias AH et al (2005). Sodium phenylbutyrate prolongs survival and regulates expression of anti-apoptotic genes in transgenic amyotrophic lateral sclerosis mice. J Neurochem 93: 1087-1098.

Song L, De Sarno P, Jope RS (2002). Central role of glycogen synthase kinase-3beta in endoplasmic reticulum stress-induced caspase-3 activation. J Biol Chem 277: 44701-44708.

Strahl BD, Allis CD (2000). The language of covalent histone modifications. Nature 403: 41-45.

Tully T, Bourtchouladze R, Scott R, Tallman J (2003). Targeting the CREB pathway for memory enhancers. Nat Rev Drug Discov 2: 267-277.

Vecsey CG, Hawk JD, Lattal KM, Stein JM, Fabian SA, Attner MA et al (2007). Histone deacetylase inhibitors enhance memory and synaptic plasticity via CREB:CBP-dependent transcriptional activation. J Neurosci 27: 6128-6140.

Wright JM, Zeitlin PL, Cebotaru L, Guggino SE, Guggino WB (2004). Gene expression profile analysis of 4-phenylbutyrate treatment of IB3-1 bronchial epithelial cell line demonstrates a major influence on heat-shock proteins. Physiol Genomics 16: 204-211. 